DOI: $10.15193 / \mathrm{ZNTJ} / 2018 / 115 / 229$

HALINA MAKAŁA

\title{
MODYFIKACJA WARTOŚCI ŻYWIENIOWEJ MIESA I PRZETWORÓW MIĘSNYCH POPRZEZ ZMIANY ILOŚCI I SKŁADU TŁUSZCZÓW ORAZ OGRANICZANIE ZAWARTOŚCI SOLI
}

\begin{abstract}
Streszczenie
Na podstawie danych literaturowych w pracy przedstawiono analizę wybranych czynników wpływających na poprawę wartości odżywczej mięsa i przetworów mięsnych. Szczególną uwagę zwrócono na modyfikację wartości żywieniowej mięsa i przetworów mięsnych poprzez zmiany ilości i składu thuszczów oraz ograniczenie zawartości soli. Omówiono składniki odżywcze występujące w mięsie i przetworach mięsnych, podano zawartość wybranych składników mineralnych i witamin oraz zawartość kwasu linolowego (CLA) w różnych rodzajach mięsa. Przedstawiono charakterystykę thuszczów zwierzęcych wykorzystywanych w przemyśle mięsnym, ich rolę żywieniową oraz technologiczną. Omówiono znaczenie olejów roślinnych w modyfikacji profilu kwasów tłuszczowych zarówno surowca mięsnego, jak i przetworów mięsnych, której celem jest poprawa wartości żywieniowej tych produktów. Efekt ten można osiągnąć metodami genetycznymi lub żywieniowymi. Ilość i jakość tłuszczu w tuszy w znacznym stopniu zależy od składu komponentów paszowych. Zastosowanie nasion roślin oleistych lub olejów w żywieniu tuczników i drobiu w istotny sposób wpływa na skład kwasów tłuszczowych tłuszczu zapasowego i lipidów mięsa. Scharakteryzowano metody ograniczania zawartości soli w przetworach mięsnych. Jednym z istotnych kierunków działań w celu obniżenia ilości soli spożywanej z produktami przemysłowo przetworzonymi może być zmniejszanie jej dodatku do wyrobów oraz aktywne kształtowanie przyzwyczajeń konsumentów do mniej słonego smaku. Skutecznym sposobem ograniczania zawartości soli w mięsie i przetworach mięsnych może okazać się zastosowanie technologii wysokich ciśnień.
\end{abstract}

Słowa kluczowe: mięso i przetwory mięsne, wartość żywieniowa, modyfikacja tłuszczów zwierzęcych, ograniczanie soli

Dr inż. H. Makała, Zakład Technologii Mięsa i Ttuszczu, Instytut Biotechnologii Przemystu RolnoSpożywczego im. prof. Wactawa Dąbrowskiego, ul. Jubilerska 4, 04-190 Warszawa.

Kontakt: halina.makala@ibprs.pl 


\section{Wprowadzenie}

Do najważniejszych czynników ryzyka przedwczesnego zgonu, które związane są z dietą, w Unii Europejskiej zaliczono: wysokie ciśnienie krwi, wysoki poziom cholesterolu i wskaźnik masy ciała, spożywanie niewystarczającej ilości owoców i warzyw, nadużywanie alkoholu. Kompetencje w zakresie przyznawania środków na ochronę zdrowia publicznego w celu rozwiązania powyższych problemów należą do poszczególnych krajów UE. Wybrane inicjatywy koordynowane są na poziomie unijnym, np. rozwiązywanie problemów zdrowotnych związanych z dietą, takich jak otyłość czy cukrzyca [53].

Z badań Światowej Organizacji Zdrowia (WHO) wynika, że żywienie stało się główną, poddającą się modyfikacjom, determinantą przewlekłych chorób niezakaźnych. Zwiększa się bowiem liczba dowodów naukowych uzasadniających opinię, że zmiany diety mają duży wpływ, zarówno korzystny, jak i szkodliwy na zdrowie w ciągu całego życia. Zmiany diety mogą nie tylko oddziaływać na obecny stan zdrowia, ale też zdecydować o tym, czy człowiek zachoruje czy też nie na nowotwory, choroby układu krążenia, cukrzycę [25].

W ostatnich latach żywność przestaje być postrzegana jedynie jako źródło składników odżywczych służących pokryciu odpowiednich potrzeb pokarmowych człowieka i coraz częściej zwraca się uwagę na jej właściwości funkcjonalne, czyli pozytywne oddziaływanie na stan zdrowia. Współczesna dieta jest jedną z najistotniejszych przyczyn występowania szeregu zaburzeń metabolicznych i stanowi podłoże rozwoju wielu chorób dietozależnych - otyłości, miażdżycy, niektórych postaci nowotworów. Wzrastająca częstotliwość ich występowania rodzi świadomość konieczności modyfikowania składu produktów spożywczych w kierunku zwiększenia w nich udziału substancji bioaktywnych, korzystnie wpływających na funkcjonowanie organizmu $[14,35,44$, $52,54]$.

Również konsumenci mięsa i przetworów mięsnych, świadomi zależności między sposobem żywienia a stanem zdrowia, coraz częściej poszukują produktów o podwyższonej wartości odżywczej i/lub obniżonej wartości energetycznej w porównaniu z ich dotychczasowymi odpowiednikami oferowanymi na rynku $[9,19]$.

Jedną z ważniejszych przyczyn zaleceń ograniczania spożycia mięsa i produktów mięsnych jest dość duża zawartość w nich tłuszczów, będących istotnym źródłem cholesterolu oraz kwasów tłuszczowych nasyconych. Zwraca się ponadto uwagę na stosunkowo dużą zawartość soli kuchennej w przetworach, a także na różnorodność substancji dodatkowych stosowanych przy przetwarzaniu mięsa. Powszechność konsumpcji produktów mięsnych $\mathrm{w}$ diecie stała się bodźcem do podjęcia działań w kierunku poprawy ich jakości żywieniowej. Obecnie działania producentów żywności ukierunkowane są na modyfikację składu i wartości odżywczej produktów mięsnych $[18,20]$. 
Celem pracy była ocena na podstawie danych literaturowych wybranych czynników wpływających na wartość odżywczą mięsa i przetworów mięsnych i możliwości jej poprawy.

\section{Sladniki odżywcze i pokarmowe występujące w mięsie i przetworach mięsnych}

Na jakość mięsa wpływają czynniki przyżyciowe, postępowanie przedubojowe, przemiany poubojowe oraz podział tuszy i przygotowanie elementów kulinarnych. Mięso i przetwory mięsne zaliczane są do najbogatszych źródeł białka. W przeliczeniu na $100 \mathrm{~g}$ produktu zawartość białka w mięsie surowym (tkance mięśniowej) kształtuje się średnio na poziomie $22 \div 23 \%$, a wzrasta w mięsie po obróbce termicznej. Skład aminokwasowy białek mięsa jest dobrze zbilansowany, tzn. zawierają one wszystkie aminokwasy egzogenne, a ich wzajemne proporcje są korzystne ze względu na potrzeby człowieka. W wyniku obróbki termicznej, jak również procesów dehydratacyjnych, zmniejsza się znacznie biodostępność aminokwasów, co oznacza, że wartość odżywcza mięsa i przetworów mięsnych poddawanych takim zabiegom będzie mniejsza niż mięsa surowego. Do obniżenia wartości odżywczej przyczyniają się dodatkowo straty witamin w czasie obróbki termicznej mięsa. Ważne jest zatem, aby procesy przetwarzania prowadzić w warunkach umożliwiających zachowanie jak największej wartości odżywczej produktu $[1,3,23]$.

Wartość energetyczna mięsa zależy w znacznym stopniu od zawartości tłuszczu $\mathrm{w}$ danym elemencie. W przypadku mięsa chudego wartość ta zawiera się w przedziale $100 \div 150 \mathrm{kcal} / 100 \mathrm{~g}$ i wzrasta wraz ze wzrostem zawartości thuszczu, gdyż wartość energetyczna thuszczu zwierzęcego wynosi ponad $700 \mathrm{kcal} / 100 \mathrm{~g}$.

Mięso jest istotnym źródłem składników mineralnych, szczególnie dobrze przyswajalnego żelaza hemowego. Najwięcej znajduje się go w mięsie końskim, wołowym i cielęcym. Mięso kurczęce i indycze zawiera niewiele tego składnika. Mięso zawiera też znaczne ilości witamin z grupy $\mathrm{B}$, szczególnie witaminy $\mathrm{B}_{12}$, której podstawowym źródłem są produkty pochodzenia zwierzęcego. W diecie typu zachodniego mięso i jego przetwory pokrywają ok. $70 \%$ zapotrzebowania na wit. $\mathrm{B}_{12}[3,23]$. Zawartość wybranych witamin i składników mineralnych przedstawiono w tab. 1.

Zawartość tłuszczu w mięsie jest bardzo zróżnicowana w zależności od gatunku, klasy mięsności i części tuszy. Wołowina, cielęcina, mięso kurczęce i indycze charakteryzują się mniejszą zawartością tłuszczu wynoszącą $1 \div 15 \%$. Większe ilości tłuszczu zawiera thusta wieprzowina, mięso kacze i gęsie. Także przetwory mięsne, w tym wędliny, różnią się znacznie zawartością tłuszczu, co wynika z ich składu recepturowego. Można istotnie zmniejszyć wartość energetyczną posiłku, wybierając chude mięso zamiast thustego, a także przygotowując mięso bez dodatku thuszczu lub z bardzo małym jego udziałem. Preferowane jest zatem gotowanie, pieczenie lub duszenie zamiast smażenia w tłuszczu [23]. 
Tabela 1. Zawartość wybranych witamin i składników mineralnych w 100 g mięsa czerwonego Table 1. Content of selected vitamins and minerals in $100 \mathrm{~g}$ of red meats

\begin{tabular}{||c|c|c|c|c||}
\hline $\begin{array}{c}\text { Rodzaj mięsa } \\
\text { Type of meat }\end{array}$ & $\begin{array}{c}\text { Mięso wołowe } \\
\text { Beef meat }\end{array}$ & $\begin{array}{c}\text { Mięso wieprzowe } \\
\text { Pork meat }\end{array}$ & $\begin{array}{c}\text { Mięso jagnięce } \\
\text { Lamb meat }\end{array}$ & $\begin{array}{c}\text { Mięso końskie } \\
\text { Horse meat }\end{array}$ \\
\hline $\begin{array}{c}\text { Witamina } B_{1} \\
\text { Vitamin } B_{1}[\mathrm{mg}]\end{array}$ & $0,04 \div 0,08$ & $0,80 \div 1,00$ & $0,10 \div 0,12$ & $0,03 \div 0,06$ \\
\hline $\begin{array}{c}\text { Witamina } B_{2} \\
\text { Vitamin } B_{1}[\mathrm{mg}]\end{array}$ & $0,18 \div 0,24$ & 0,27 & $0,20 \div 0,23$ & $0,17 \div 0,19$ \\
\hline $\begin{array}{c}\text { Niacyna } \\
\text { Niacin }[\mathrm{mg}]\end{array}$ & $4,60 \div 5,00$ & 5,60 & $4,10 \div 5,20$ & $5,10 \div 6,00$ \\
\hline $\begin{array}{c}\text { Witamina } \mathrm{B}_{6} \\
\text { Vitamin } \mathrm{B}_{6}[\mathrm{mg}]\end{array}$ & $0,33 \div 0,52$ & 0,35 & 0,10 & $0,50 \div 0,85$ \\
\hline $\begin{array}{c}\text { Witamina } \mathrm{B}_{12} \\
\text { Vitamin } \mathrm{B}_{12}[\mathrm{mg}]\end{array}$ & $2,50 \div 4,00$ & 0,60 & 0,96 & $1,45 \div 2,60$ \\
\hline $\begin{array}{c}\text { Żelazo } \\
\text { Iron }[\mathrm{mg}]\end{array}$ & $1,60 \div 2,50$ & $0,70 \div 1,30$ & $2,00 \div 2,60$ & $3,59 \div 4,58$ \\
\hline $\begin{array}{c}\text { Cynk } \\
\text { Zinc }[\mathrm{mg}]\end{array}$ & $3,20 \div 5,50$ & $1,50 \div 3,30$ & $2,3 \div 4,5$ & b.d. \\
\hline $\begin{array}{c}\text { Selen } \\
\text { Selenium }[\mu \mathrm{g}]\end{array}$ & $9,0 \div 44,0$ & $16,0 \div 36,1$ & $11,0 \div 23,4$ & b.d. \\
\hline
\end{tabular}

Objaśnienie / Explanatory note:

b.d. - brak danych / no data

Źródło / Source: opracowanie własne na podstawie [11, 13, 23] / the author's own study based on: [11, 13, 23]

Mięso jest źródłem sprzężonego kwasu linolowego (CLA), któremu przypisuje się szereg właściwości prozdrowotnych. Zawartość CLA w mięsie przeżuwaczy zależy od rodzaju stosowanej paszy. Największa jest z reguły latem przy żywieniu pastwiskowym, gdy udział kwasu linolowego w diecie zwierząt jest duży. Podejmowane są badania mające na celu zwiększenie zawartości sprzężonych dienów kwasu linolowego w mięsie wieprzowym poprzez dodatek do pasz trzody chlewnej preparatów CLA [44]. Przykładową średnią zawartość CLA w mięsie przedstawiono w tab. 2.

Mięso, a szczególnie podroby, to znaczące źródło cholesterolu. Zawartość cholesterolu w mięsie zawiera się w przedziale $60 \div 90 \mathrm{mg} / 100 \mathrm{~g}$. Jest ona zależna od przyżyciowej aktywności danego mięśnia oraz zawartości tłuszczu. Tłuste mięso i produkty mięsne zawierają dużo nasyconych kwasów tłuszczowych SFA (do $50 \%$ w wołowinie, ok. $40 \%$ w wieprzowinie). W profilaktyce miażdżycy i choroby wieńcowej ich spożycie powinno być zatem ograniczone [13]. Z tych względów zalecane jest więc mięso chude bez skóry oraz przetwory z mięsa o niewielkiej zawartości tłuszczu.

Metody genetyczne i żywieniowe umożliwiły zredukowanie tłuszczu w tuszy zwierząt oraz modyfikację kwasów tłuszczowych [3]. Najprostszym sposobem zredu- 
kowania tłuszczu w przetworach mięsnych jest użycie surowca o małej zawartości tłuszczu, m.in. takiego, z którego usunięto zewnętrzne i międzymięśniowe złogi tkanki thuszczowej. Sposób ten jednak bardzo zwiększa cenę produktu. Innym sposobem zmniejszenia zawartości tłuszczu w produkcie jest wprowadzenie w jego miejsce zamienników białkowych, węglowodanowych lub syntetycznych substancji thuszczopodobnych. Przetwory mięsne o obniżonej zawartości tłuszczu będą więc spełniały kryteria stawiane środkom spożywczym specjalnego przeznaczenia żywieniowego, np. dla osób z zaburzeniami gospodarki lipidowej, z nadmierną masą ciała i otyłych [52].

Tabela 2. Zawartość CLA w mięsie

Table 2. CLA content in meat

\begin{tabular}{|c|c||}
\hline $\begin{array}{c}\text { Rodzaj mięsa } \\
\text { Type of meat }\end{array}$ & $\begin{array}{c}\text { Zawartość CLA [mg/g tłuszczu] } \\
\text { CLA content [mg/g fat] }\end{array}$ \\
\hline Mięso wołowe / Beef meat & $1,2 \div 14$ \\
\hline Mięso cielęce / Veal meat & 2,7 \\
\hline Mięso jagnięce / Lamb meat & 5,8 \\
\hline Mięso wieprzowe / Pork meat & 0,6 \\
\hline $\begin{array}{c}\text { Mięso drobiowe - kurczęce } \\
\text { Poultry meat - chickens }\end{array}$ & 0,9 \\
\hline $\begin{array}{c}\text { Mięso drobiowe - indycze } \\
\text { Chicken meat - turkey }\end{array}$ & 2,6 \\
\hline
\end{tabular}

Źródło / Source: opracowanie własne na podstawie [13] / the author’s own study based on [13]

Odpowiednie zestawienie paszy zwierząt lub dodatek do niej niektórych substancji, w tym tokoferoli (witaminy E), selenu i innych umożliwia uzyskanie mięsa o pożądanym składzie, w tym o większej zawartości witaminy E, selenu, przeciwutleniaczy polifenolowych, koenzymu Q10. Wpływa to nie tylko na poprawę cech sensorycznych produktu, ale i zwiększa jego atrakcyjność pod względem dietetycznym. Podobnie dodatek niektórych substancji w procesie przetwarzania mięsa, np. zamienników tłuszczowych (przez co zredukowana zostanie zawartość tłuszczu) czy przypraw bogatych w przeciwutleniacze polifenolowe, zwiększy użyteczność produktów w zestawianiu diety dla osób o specjalnych wymaganiach. Wykorzystanie probiotyków (np. bakterii z rodzaju Lactobacillus) i prebiotyków (np. inuliny) do produkcji fermentowanych przetworów mięsnych poszerza asortyment produktów o pożądanym składzie [1, 44].

\section{Charakterystyka i wartość żywieniowa tłuszczów zwierzęcych}

Po mięsie thuszcze zwierzęce stanowią podstawową grupę surowców wytwarzanych i wykorzystywanych w przemyśle mięsnym. W produkcji przetworów mięsnych odgrywają one kluczową rolę w kształtowaniu ich tekstury, wpływają na ich wartość 
energetyczną i profil sensoryczny. Ilość i jakość surowca tłuszczowego uzyskiwanego ze zwierząt rzeźnych uzależniona jest od wielu czynników, takich jak: warunki chowu i żywienia zwierząt, genotyp, wiek i płeć zwierzęcia, lokalizacja tkanki tłuszczowej. Zawartość takich składników, jak: białko, woda, tłuszcz, w tym kwasy tłuszczowe, witaminy i cholesterol decydują o wartości energetycznej i przydatności technologicznej tłuszczu $[2,3,5,42]$.

Konsystencja, spoistość, jędrność oraz wrażliwość na utlenianie decydują o przydatności tkanki tłuszczowej do przetwarzania. Niepożądane przemiany lipidów mogą ograniczać możliwości technologicznego i żywieniowego wykorzystania surowców, zwłaszcza pochodzenia zwierzęcego [7, 10, 32, 45, 50]. Trudne jest uzyskanie dobrej jakości tłuszczu zwierzęcego w zakresie wartości odżywczej, technologicznej i sensorycznej. Tkanka thuszczowa powinna mieć białą barwę, jędrną konsystencję i odznaczać się stabilnością w stosunku do czynników utleniających [21, 42].

Krupska i Olkiewicz [22] badali skład kwasów tłuszczowych wybranych elementów zasadniczych tuszy wieprzowej: słoniny, podgardla, pachwiny, boczku i karkówki, najczęściej wykorzystywanych w przetwórstwie mięsa. W tab. 3. przedstawiono zawartość poszczególnych grup kwasów tłuszczowych w badanych elementach, tj. nasyconych kwasów tłuszczowych (SFA), jednonienasycnych kwasów tłuszczowych (MUFA), wielonienasyconych kwasów tłuszczowych (PUFA), kwasów nienasyconych ogółem (UFA) oraz przedstawiono wyliczone stosunki MUFA/SFA, PUFA/SFA oraz stopień nasycenia tłuszczu $\mathrm{S} / \mathrm{U}$, gdzie $\mathrm{S}=\mathrm{SFA}$, a $\mathrm{U}=\mathrm{UFA}$.

Wymienieni wyżej autorzy [22] stwierdzili, że tłuszcze karkówki charakteryzowały się istotnie największą zawartością SFA $(39,2 \div 41,0 \%)$ i istotnie najmniejszą zawartością UFA $(9,3 \div 10,0 \%)$, co skutkowało istotnie najwyższym stopniem nasycenia tłuszczu $(0,66 \div 0,71)$ i najniższym stosunkiem MUFA/SFA $(1,2 \div 1,3)$ oraz PUFA/SFA $(0,2)$. Tłuszcze podgardla charakteryzowały się istotnie najmniejszą zawartością SFA $(34,4 \div 35,6 \%)$ i istotnie największą zawartością UFA $(63,8 \div 64,9 \%)$, co skutkowało istotnie najniższym stopniem nasycenia tłuszczu $(0,54 \div 0,57)$ i najwyższym stosunkiem MUFA/SFA $(1,5)$ oraz niemal najwyższym stosunkiem PUFA/SFA $(0,3)$.

Dla prawidłowego funkcjonowania organizmu istotne jest zachowanie właściwego stosunku PUFA z grupy $n$-6 i $n$-3. Rekomendowany przez żywieniowców stosunek kwasów tłuszczowych $n$ - 6 do $n$-3 zawartych w diecie powinien wynosić $(5: 1) \div$ $(3: 1)$. W diecie człowieka stosunek ten wynosi $(15: 1) \div(20: 1)$, czyli jest znacznie wyższy od zalecanego, chociaż według najnowszych zaleceń odchodzi się już od takiego podejścia. Przetwory mięsne wzbogacone w kwasy thuszczowe $\mathrm{z}$ rodziny omega3 mogą zatem korzystnie wpływać na zdrowie konsumentów [16, 40, 51]. 
Tabela 3. Średnia zawartość SFA, MUFA, PUFA, stopień nasycenia tłuszczu oraz indeks $n-6 / n-3$ w badanych próbkach tłuszczu [\%]

Table 3. Average content of SFA, MUFA, PUFA, saturation, and $n-6 / n-3$ index in the fat samples analysed [\%]

\begin{tabular}{|c|c|c|c|c|c|c|c|c|c|}
\hline \multirow{3}{*}{$\begin{array}{c}\text { Kwasy } \\
\text { thuszczowe } \\
\text { wolne } \\
\text { Fatty acids }\end{array}$} & \multicolumn{5}{|c|}{$\begin{array}{c}\text { Tłuszcze zewnętrzne } \\
\text { External fats }\end{array}$} & \multicolumn{4}{|c|}{$\begin{array}{l}\text { Thuszcze wewnętrzne } \\
\text { Internal fats }\end{array}$} \\
\hline & Słonina & Podgardle & Pachwina & Boczek & Karkówka & Podgardle & Pachwina & Boczek & Karkówka \\
\hline & $\begin{array}{l}\text { karkowa } \\
\text { Back fat }\end{array}$ & Jowl & Groin & Belly & Neck & Jowl & Groin & Belly & Neck \\
\hline SFA (S) & $36,6^{\mathrm{ab}}$ & $35,6^{\mathrm{ab}}$ & $37,4^{\mathrm{bc}}$ & $37,7^{\text {bc }}$ & $39,2^{\mathrm{cd}}$ & $34,4^{\mathrm{a}}$ & $37,2^{\mathrm{bc}}$ & $37,4^{\text {bc }}$ & $41,0^{\mathrm{d}}$ \\
\hline MUFA & $49,7^{\mathrm{ab}}$ & $53,5^{d}$ & $52,3^{\text {cd }}$ & $52,0^{\text {cd }}$ & $51,3^{\mathrm{c}}$ & $53,2^{\mathrm{d}}$ & $51,3^{\mathrm{c}}$ & $50,9^{\mathrm{b}}$ & $48,6^{\mathrm{a}}$ \\
\hline PUFA & $13,3^{\mathrm{e}}$ & $10,3^{\mathrm{b}}$ & $9,9^{\mathrm{b}}$ & $9,9^{b}$ & $9,3^{\mathrm{a}}$ & $11,7^{\mathrm{d}}$ & $11,0^{\mathrm{c}}$ & $11,1^{\mathrm{c}}$ & $10,0^{b}$ \\
\hline UFA (U) & $63,0^{\text {cd }}$ & $63,8^{\mathrm{d}}$ & $62,2^{\mathrm{ab}}$ & $61,9^{\mathrm{ab}}$ & $60,6^{\mathrm{ab}}$ & $64,9^{\mathrm{d}}$ & $62,3^{\mathrm{b}}$ & $62,0^{\mathrm{ab}}$ & $58,6^{\mathrm{a}}$ \\
\hline MUFA / SFA & 1,4 & 1,5 & 1,4 & 1,4 & 1,3 & 1,5 & 1,4 & 1,4 & 1,2 \\
\hline PUFA / SFA & 0,4 & 0,3 & 0,3 & 0,3 & 0,2 & 0,3 & 0,3 & 0,3 & 0,2 \\
\hline $\begin{array}{c}\text { Stopień } \\
\text { nasycenia } \\
\text { tłuszczu }(\mathrm{S} / \mathrm{U}) \\
\text { Saturation } \\
\text { index }(\mathrm{S} / \mathrm{U})\end{array}$ & $0,58^{\mathrm{ab}}$ & $0,57^{\mathrm{ab}}$ & $0,61^{\mathrm{bc}}$ & $0,61^{\mathrm{bc}}$ & $0,66^{\mathrm{c}}$ & $0,54^{\mathrm{a}}$ & $0,61^{\mathrm{bc}}$ & $0,61^{\mathrm{bc}}$ & $0,71^{\mathrm{d}}$ \\
\hline$\sum n-6 / \sum n-3$ & $11,8^{\mathrm{c}}$ & $11,0^{\mathrm{a}}$ & $11,2^{\mathrm{ab}}$ & $11,9^{\mathrm{c}}$ & $11,3^{\mathrm{b}}$ & $11,2^{\mathrm{ab}}$ & $11,3^{\mathrm{b}}$ & $11,4^{\mathrm{b}}$ & $10,9^{\mathrm{a}}$ \\
\hline
\end{tabular}

Objaśnienia / Explanatory notes:

SFA (S) - nasycone kwasy thuszczowe / saturated fatty acids; MUFA - jednonienasycone kwasy thuszczowe / monounsaturated fatty acids; PUFA - wielonienasycone kwasy thuszczowe / poliunsaturated fatty acids; UFA (U) - suma MUFA + PUFA / total of MUFA and PUFA; $a, b, c$ - wartości średnie oznaczone różnymi literami różną się statystycznie istotnie $(p<0,05) /$ mean values denoted by different letters differ statistically significantly $(\mathrm{p}<0.05)$.

Źródło / Source: opracowanie własne na podstawie [22] / the author's own study based on [22]

\section{Wzbogacanie mięsa i przetworów mięsnych w kwasy thuszczowe}

Oczekiwania konsumentów mięsa dotyczą takich aspektów, jak: minimalizacja zawartości tłuszczu i cholesterolu oraz poprawa profilu kwasów tłuszczowych, w tym zwiększenie zawartości CLA, ważnego czynnika zdrowotnego [40, 45].

Skład kwasów tłuszczowych mięsa można zmieniać już na etapie chowu zwierząt poprzez żywienie paszą zawierającą pożądane składniki. Uzyskuje się surowiec o wyższej wartości odżywczej lub o cechach żywności funkcjonalnej. Modyfikacje takie można osiągać także przez krzyżowanie odpowiednich ras zwierząt w obrębie gatunku. Sposobem na zwiększenie udziału sprzężonych dienów kwasu linolowego może być też stosowanie dodatku preparatu CLA na etapie produkcji wybranych asortymentów przetworów mięsnych [44]. 
Poprawę jakości i profilu składu kwasów tłuszczowych w przetworach mięsnych można uzyskać poprzez dodatek różnorodnych zamienników tłuszczu zwierzęcego z grupy sacharydów lub/i olejów roślinnych. Innym sposobem wzrostu udziału w diecie niezbędnych nienasyconych kwasów tłuszczowych z rodziny $n-3$, który nie powoduje zmian w nawykach żywieniowych, może być wzbogacanie produktów mięsnych olejem roślinnym oraz rybnym i/lub częściowa zamiana thuszczu zwierzęcego thuszczem roślinnym. Tłuszcz zwierząt rzeźnych korzystnie wpływa na właściwości gotowego produktu, m.in. na smakowitość, wygląd i konsystencję. Zastąpienie go olejem roślinnym lub rybnym nie jest łatwe bez zmiany jakości gotowego produktu $[19,33$, $37,41,50]$.

O przydatności tych olejów do polepszania cech zdrowotnych thuszczu w wyrobach mięsnych innych grup asortymentowych świadczą wyniki badań dotyczące m.in. kiełbas parzonych i dojrzewających. Działania takie nie powinny jednak skutkować obniżeniem jakości i trwałości przetworów mięsnych. Jedną z metod poprawy stabilności oksydacyjnej lipidów i jakości mikrobiologicznej produktów wzbogaconych w oleje jest stosowanie przeciwutleniaczy pochodzenia roślinnego [26, 29, 32, 34].

Pyrcz i wsp. [46] wykazali, że 50-procentowa substytucja słoniny olejem rzepakowym w parówkach nie wpływa na zmianę ich cech sensorycznych, takich jak: smak, zapach, barwa i konsystencja wyrobów. Pelser i wsp. [41] zauważyli jednak, że wyższe wyniki ogólnej akceptacji uzyskano w przypadku kiełbas kontrolnych w porównaniu z produktami, w których $20 \%$ słoniny zastąpiono olejem lnianym. Choi i wsp. [7] stwierdzili, że możliwe jest zastąpienie słoniny olejem rzepakowym w ilości do $25 \%$ bez niekorzystnego wpływu na parametry jakościowe wyrobów. Makała i wsp. [33] wykazali, że modelowe wyroby mięsne, w których składzie surowcowym użyto thuszczu twardego (słoniny) czy też podgardla charakteryzowały się wysokim stosunkiem PUFA $n-6$ : PUFA $n$-3, wynoszącym odpowiednio: 6,62 i 7,91. Dodatek oleju lnianego spowodował korzystną żywieniowo zmianę proporcji PUFA $n-6$ : PUFA $n-3$ do poziomu odpowiednio: 2,87 i 4,72. Podobnie stwierdził Kühne [24], który wykazał, że dodatek ziaren lnu w ilości odpowiednio: 4 i $10 \mathrm{~g} / \mathrm{kg}$ w żywieniu świń wpłynął na obniżenie proporcji kwasów tłuszczowych z rodziny $n-6$ i $n$-3 z 8,1 do poziomu 2,5. Rycielewska i Słowiński [50] dowiedli, że zastąpienie podgardla wieprzowego olejem rzepakowym tłoczonym na zimno powodowała poprawę stabilności oksydacyjnej oraz stosunku kwasów tłuszczowych $n-6$ do $n-3$ w modelowych kiełbasach homogenizowanych bezpośrednio po wytworzeniu i po 21-dniowym przechowywaniu. Autorzy wykazali, że w kiełbasach homogenizowanych maksymalna ilość podgardla wymienianego na olej rzepakowy nie powinna przekraczać $25 \%$ (przy dodatku tłuszczu na poziomie $20 \%$ ). Zapewnia to wytworzenie produktów bez istotnego obniżenia ich jakości technologicznej i sensorycznej. Modzelewska-Kapituła i wsp. [36] ocenili wpływ częściowego zastąpienia słoniny olejem rzepakowym na skład chemiczny, wła- 
ściwości fizyczne i organoleptyczne modelowych drobno rozdrobnionych wyrobów mięsnych i stwierdzili, że zamiana thuszczu zwierzęcego olejem rzepakowym nie spowodowała zmian wartości $\mathrm{pH}$ wyrobów ani parametrów barwy, wpłynęła natomiast na twardość, sprężystość, żujność, gumowatość oraz konsystencję i związanie wyrobów. Cegiełka [6] wykazała, że w recepturze burgerów drobiowych możliwa jest wymiana $20 \%$ podgardla na oleje roślinne $\mathrm{z}$ jednoczesnym dodatkiem wybranego preparatu błonnika spożywczego: inuliny lub błonnika pszennego. Zastosowane modyfikacje recepturowe skutkowały polepszeniem wartości żywieniowej burgerów, zmniejszoną zawartością tłuszczu, korzystniejszymi żywieniowo proporcjami kwasów tłuszczowych.

Opisane działania nie powinny skutkować obniżeniem jakości i trwałości przetworów mięsnych. WNKT dodane do przetworów mięsnych podlegają podczas przechowywania przemianom nagromadzonych hydroksynadtlenków do wtórnych produktów oksydacji, tj. aldehydów i ketonów [51]. Jedną z metod poprawy stabilności oksydacyjnej lipidów i jakości mikrobiologicznej produktów wzbogaconych w oleje jest zastosowanie przeciwutleniaczy pochodzenia roślinnego [8, 26, 29, 33, 34]. W celu ograniczenia natężenia przemian oksydacyjnych należy zastosować dodatek antyoksydantów pochodzących np. z przypraw, co potwierdzają między innymi badania przeprowadzone przez Oberdicka [38] oraz Szczepanika [55].

\section{Metody ograniczenia zawartości soli w przetworach mięsnych}

W przetwórstwie mięsa powszechnie używana jest sól. Zawartość chlorku sodu w świeżym mięsie waha się w granicach $115 \div 280 \mathrm{mg} \mathrm{NaCl} / 100 \mathrm{~g}$, w kiełbasach surowych $-2540 \div 6350 \mathrm{mg} \mathrm{NaCl} / 100 \mathrm{~g}$, a w kiełbasach parzonych $-2030 \div$ $4320 \mathrm{mg} \mathrm{NaCl} / 100 \mathrm{~g}$ [ 18].

Jednym $\mathrm{z}$ istotnych kierunków działań w celu obniżenia ilości soli spożywanej z produktami przemysłowo przetworzonymi może być zmniejszenie jej dodatku do wyrobów oraz aktywne kształtowanie przyzwyczajeń konsumentów do mniej słonego smaku. Pomocne w tym celu jest umieszczanie przez producenta wiarygodnej informacji dotyczącej zawartości chlorku sodu lub sodu w określonej ilości produktu. Od 13 grudnia 2014 r. stosowane jest w Polsce Rozporządzenie Parlamentu Europejskiego i Rady (UE) nr 1169/2011 w sprawie przekazywania konsumentom informacji dotyczących żywności. W ramach tego rozporządzenia obowiązkowe jest podawanie na opakowaniach informacji o: wartości energetycznej, zawartości tłuszczu, kwasów tłuszczowych nasyconych, węglowodanów, cukrów, białka i soli [28, 48].

Tendencje do zmniejszania zawartości chlorku sodu w różnych grupach przetworów mięsnych, w tym w wędzonkach, obserwowano już we wcześniejszych badaniach $[15,17,30,56]$. Między innymi Makała i wsp. [31] przebadali dostępne na rynku parówki i wykazali, że w ocenianych sortymentach średnia zawartość soli kształtowała 
się na poziomie $1,9 \div 2,3 \%$ i była istotnie mniejsza niż wymagana na podstawie aktualnej wówczas PN-A-82007:1996/Az1:1998 [58]. Szymański i wsp. [56] ocenili rynkowe wędzonki oraz kiełbasy suszone średnio i drobno rozdrobnione w latach 2000 2008 i stwierdzili w nich dość zróżnicowaną zawartość chlorku sodu z tendencją do obniżania jego poziomu. Wykazali, że zawartość chlorku sodu w wędzonkach uległa zmniejszeniu średnio o $0,52 \mathrm{~g} / 100 \mathrm{~g}$ produktu.

Zachęca się także do stosowania ziół i przypraw oraz zamienników soli, np. chlorku potasu [57]. Ruusunen i Puolanne [49] przedstawili dobre efekty uzyskane po zastosowaniu przemysłowych mieszanek soli, w których składzie znajdowało się $58 \%$ $\mathrm{NaCl}, 27 \% \mathrm{KCl}, 12 \% \mathrm{MgCl}_{2}$ lub $\mathrm{MgSO}_{4}$ (Pan-Salt), do produkcji kiełbas parzonych. W celu osiągnięcia pożądanego przez konsumentów smaku najczęściej wykorzystywane są: czosnek, kminek, jałowiec, szafran, papryka, anyż, goździki, cynamon oraz ziele angielskie. Uwydatniają one walory smakowe i zapachowe produktów i potraw oraz wzmagają apetyt, stymulują wydzielanie soków trawiennych i poprawiają perystaltykę jelit [4]. Do przypraw zalecanych w leczniczych dietach niskosodowych zalicza się: gałkę muszkatołową, majeranek, tymianek, imbir, czosnek i słodką paprykę [27].

Skutecznym sposobem ograniczania zawartości soli w mięsie i przetworach mięsnych może okazać się zastosowanie technologii wysokich ciśnień (HHP). O'Flynn i wsp. [39] porównali wpływ działania wysokiego ciśnienia na mięso wieprzowe w przygotowaniu kiełbas o małej zawartości sodu. Doświadczenie polegało na poddaniu próbek mięsa o różnej zawartości soli $(0,5,1,0,1,5,2,0$ i $2,5 \%)$ działaniu wysokiego ciśnienia - $150 \mathrm{MPa} / 5 \mathrm{~min}$. Dodatek do mięsa soli w ilości poniżej 1,5\% skutkował negatywnymi zmianami barwy, tekstury, soczystości i jędrności produktów. Wykazano, że obróbka przy $150 \mathrm{MPa}$ i zawartość soli powyżej $2 \%$ podczas produkcji kiełbas nie wywierają negatywnego wpływu na cechy sensoryczne. Grossi i wsp. [12] badali wpływ wysokiego ciśnienia hydrostatycznego (400, 600 i $800 \mathrm{MPa})$ połączony z użyciem składników, takich jak marchew i skrobia ziemniaczana w kiełbasach wieprzowych o małej zawartości soli (1,2 i 1,8 \%). Wykazali, że zastosowanie wysokiego ciśnienia może być dobrą metodą uzupełniającą proces technologiczny w celu zmniejszenia zawartości soli i zwiększenia trwałości produktu. HPP okazało się również dobrą techniką poprawy słonego smaku w szynkach suszonych pod ciśnieniem 300, 600 i $900 \mathrm{MPa}$ w ciągu $300 \mathrm{~s}$ w badaniach, które przeprowadzili Picouet i wsp. [43]. Rodrigues i wsp. [47] badali możliwości zastosowania wysokiego ciśnienia do zmniejszania zawartości soli w produkcji żywności i wykazali, że jest to technika o dużych możliwościach praktycznego zastosowania $\mathrm{z}$ uwagi na to, że mięso i produkty mięsne uważane są za ważne (drugie pod względem wielkości udziału) źródło sodu w diecie. 


\section{Podsumowanie}

Powszechność konsumpcji mięsa i przetworów mięsnych stała się bodźcem do podjęcia działań w kierunku poprawy ich jakości żywieniowej. Obecnie działania producentów żywności zmierzają do modyfikacji składu i wartości odżywczej produktów mięsnych. O wyborze mięsa przez konsumentów decyduje wiele czynników. Obok ceny mięsa i preferencji gatunku mięsa na podjęcie decyzji o jego zakupie wpływa wygląd, tj. barwa, marmurkowatość, zawartość i rozmieszczenie tłuszczu. W nie mniejszym stopniu o zakupie decyduje przekonanie konsumenta, że mięso jest bezpieczne i pochodzi od dostawcy godnego zaufania.

Modyfikacji wartości żywieniowej mięsa i przetworów mięsnych można dokonać poprzez zmiany ilości i składu tłuszczów oraz ograniczenie zawartości soli. Najprostszym sposobem zmniejszenia zawartości tłuszczu w przetworach mięsnych jest użycie surowca o małej jego ilości, wprowadzenie w jego miejsce zamienników białkowych, węglowodanowych lub syntetycznych substancji thuszczopodobnych. Przetwory mięsne o zredukowanej zawartości tłuszczu będą więc spełniały kryteria stawiane środkom spożywczym specjalnego przeznaczenia żywieniowego. Poprawę jakości i profilu składu kwasów tłuszczowych w przetworach mięsnych można uzyskać poprzez dodatek różnorodnych zamienników tłuszczu zwierzęcego z grupy sacharydów lub/i olejów roślinnych. Innym sposobem wzrostu udziału w diecie niezbędnych nienasyconych kwasów tłuszczowych z rodziny $n$-3, który nie spowoduje zmian w nawykach żywieniowych, może być wzbogacanie produktów mięsnych olejem roślinnym oraz rybnym i/lub częściowa zamiana tłuszczu zwierzęcego tłuszczem roślinnym.

Jednym z istotnych kierunków działań w celu obniżenia ilości soli spożywanej z produktami przemysłowo przetworzonymi może być zmniejszenie jej dodatku do wyrobów oraz aktywne kształtowanie przyzwyczajeń konsumentów do mniej słonego smaku. Zaleca się także stosowanie ziół i przypraw oraz zamienników chlorku sodu, np. chlorku potasu. Potencjalną metodą ograniczania zawartości soli w mięsie i przetworach mięsnych może być zastosowanie technologii wysokich ciśnień.

\section{Literatura}

[1] Bartnikowska E.: Produkty mięsne jako żywność wygodna i funkcjonalna. Przem. Spoż., 2001, 55 (10), 13-14.

[2] Bartnikowska E.: Fizjologiczne działania polienowych kwasów tłuszczowych z rodziny $n$-3. Tłuszcze Jadalne, 2008, 43 (1/2), 10-15.

[3] Blicharski T., Książek P., Pospiech E., Migdał W., Jóźwik A., Poławska E., Lisiak D.: Aktualna wartość dietetyczna wieprzowiny, jej znaczenie w diecie i wpływ na zdrowie konsumentów. Wyd. POLSUS, Warszawa 2015, ss. 37-46.

[4] Broda B., Mowszowicz J.: Przewodnik do oznaczania roślin leczniczych, trujących i użytkowych. Wyd. Nauk. PZWL, Warszawa 2000. 
[5] Cardenia V., Rodriguez-Estrada M.T., Cumella F., Sardi L., Della Casa G., Lercker G.: Oxidative stability of pork meat lipids as related to high-oleic sunflower oil and vitamin E diet supplementation and storageconditions. Meat Sci., 2011, 88, 271-279.

[6] Cegiełka A.: Zastosowanie olejów roślinnych i preparatów błonnikowych do produkcji burgerów z mięsa kurcząt. Żywność. Nauka. Technologia. Jakość, 2012, 3 (82), 88-100.

[7] Choi Y.-S., Choi J.-H., Han D.-J., Kim H.-Y., Lee M.-A., Kim H.-W., Lee J.-W., Chung H.-J., Kim C.-J.: Optimization of replacing pork back fat with grape seed oil and rice bran fiber for reduced-fat meat emulsion systems. Meat Sci., 2010, 84, 212-218.

[8] Cichosz G., Czeczot H:. Stabilność oksydacyjna thuszczów jadalnych - konsekwencje zdrowotne. Bromat. Chem. Toksykol., 2011, XLIV (1), 50-60.

[9] Decker E.A., Park Y.: Healthier meat products as functional foods. Meat Sci., 2010, 86, 49-55.

[10] Desmond E.: Reducing salt: A challenge for the meat industry. Meat Sci., 2006, 74, 188-198.

[11] Gill C.O.: Safety and storage stability of horse meat for human consumption. Meat Sci., 2005, 71, 506-513.

[12] Grossi A., Olsen K., Bolumar T., Rinnan Å., Øgendal L.H., Orlien V.: The effect of high pressure on the functional properties of pork myofibrillar proteins. Food Chem., 2016, 196, 1005-1015.

[13] Hoffmann M., Waszkiewicz-Robak B., Świderski F.: Functional food of animal origin. Meatand meat products. Nauka Przyr. Technol., 2010, 4 (5), 1-13.

[14] Jimenez-Colmenero F.: Healthier lipid formulation approaches in meatbased functional foods. Technological options for replacement of meat fats by non-meat fats. Trends Food Sci. Technol., 2007, 18 (11), 567-578.

[15] Kłossowska B.: Zmiany zawartości soli, azotynu i azotanu oraz fosforanów w wybranych krajowych produktach mięsnych w latach 1994-1999. Rocz. IPMiTł., 1999, 36, 179-189.

[16] Kolanowski W.: Długołańcuchowe wielonienasycone kwasy tłuszczowe omega-3 - znaczenie zdrowotne w obniżaniu ryzyka chorób cywilizacyjnych. Bromat. Chem. Toksykol., 2007, 3, 229-237.

[17] Konieczny P., Pospiech E., Politowska I.: Wpływ soli morskiej na wybrane właściwości frakcji tłuszczowej mięsa bydlęcego. Żywność. Nauka. Technologia. Jakość, 2005, 3 (44) Supl., 108-120.

[18] Konieczny P., Górecka D.: Mięso w żywieniu człowieka, aktualne kierunki w produkcji wyrobów mięsnych. Przem. Spoż., 2011, 3 (65), 28-31.

[19] Kowalski R., Pyrcz J.: Innowacyjne dodatki technologiczne w przemyśle mięsnym. Przem. Spoż., 2009, 3 (63), 28-32.

[20] Kozań K., Guzek D., Lange E., Głąbska D., Włodarek D., Wierzbicka A.: Produkty mięsne należące do grupy żywności funkcjonalnej z uwzględnieniem potrzeb chorych na nieswoiste stany zapalne jelit. Zdrowie Publ. i Zarz., 2012, 10 (2), 65-71.

[21] Krasnowska G., Salejda A.: Wybrane cechy jakościowe tłuszczu pochodzącego z tusz tuczników różnych grup genetycznych. Żywność. Nauka. Technologia. Jakość, 2008, 2 (57), 95-105.

[22] Krupska A., Olkiewicz M.: Wpływ składu puli kwasów tłuszczowych na wybrane wyróżniki badanych tłuszczy pochodzących z wybranych elementów zasadniczych tuszy wieprzowej. PNiTRS, 2012, LXVII (1), 43-52.

[23] Kunachowicz H., Nadolna I., Iwanow K., Przygoda B.: Wartość odżywcza produktów spożywczych i typowych potraw. Wyd. VI. Wyd. Nauk. PZWL, Warszawa 2012.

[24] Kühne D.: Aktuelles aus der internationalen Fleischforschung. Futterung von Leinsaat zur Errholung des Gehalts an Omega-3 Fettsauren in Schweinfett. Fleichwirtschaft, 2000, 80 (6), 81-83.

[25] Kwasek M.: Międzynarodowe zalecenia żywieniowe. Przem. Spoż., 2016, 12 (70), 2-7. 
[26] Lopéz-Lopéz I., Cofrades S., Jimenéz-Colmenero F.: Low-fat frankfurters enriched with n-3 PUFA and edible seaweed: Effect of olive oil and chilled storage on physicochemical, sensory and microbial characteristics. Meat Sci., 2009, 83, 148-154.

[27] Lutomski J.: Znaczenie ziół w terapii i dietetyce. Wiad. Zielarskie, 2001, 43 (06), 4-7.

[28] Majchrzak B.: Nowe wymagania dotyczące znakowania ważne od 13 grudnia 2014 r. Przem. Spoż., 2014, 8 (68), 26-30.

[29] Makała H., Kern-Jędrychowski J.: Ocena modelowych przetworów mięsnych z dodatkiem olejów z ryb w aspekcie charakterystyki profilu kwasów tłuszczowych i przebiegu zmian oksydacyjnych. Rocz. IPMiTł., 2006, XLIV (2), 95-106.

[30] Makała M., Tyszkiewicz S., Wawrzyniewicz M.: Charakterystyka parówek rynkowych przetworów mięsnych. Gosp. Mięsna, 2006, 8, 20-26.

[31] Makała H., Tyszkiewicz S., Wawrzyniewicz M.: Jakość popularnych rynkowych kiełbas średnio rozdrobnionych. Rocz. IPMiTł, 2007, XLV (2), 133-145.

[32] Makała H., Kern-Jędrychowski J.: Rola surowca thuszczowego w modelowych przetworach mięsnych w kształtowaniu tekstury i jakości sensorycznej. Rocz. IPMiTł., 2007, XLV (2), 95-106.

[33] Makała H.: Effect of enriching model meat products with oils, abundant in polyunsaturated fatty acids on the selected quality parameters. EJPAU, 2007, 10 (2), \#15.

[34] Makała H., Kern-Jędrychowski J., Jerzewska M.: Wpływ surowców tłuszczowych na charakterystykę profilu kwasów tłuszczowych w modelowych emulsjach. Tłuszcze Jadalne, 2007, 42 (1/2), 102110.

[35] Migdał W., Pieszka M., Barowicz T., Janik A., Wojtysiak D., Pustkowiak H., Nowak J., Kozioł A.: Modyfikowanie profilu kwasów tłuszczowych mięsa zwierząt rzeźnych - za i przeciw. Rocz. IPMiTł, 2008, XLVI (1), 111-123.

[36] Modzelewska-Kapituła M., Ostoja H., Cierach M.: Influence of rape-seed oil on sensory and textural properties of model comminuted meat products. Nauka Przyr. Technol., 2012, 6 (2), \#32.

[37] Nitsch P.: Auf die Mischung kommt es an. Omega-3-Fettsauren als funktioneller Zusatz In Fleischerzeugnissen. Fleichwirtschaft, 2007, 2 (87), 46-51.

[38] Oberdick R.: Naturliche Antioxidanten aus Rosmarin und Salbei. Fleichwirtschaft, 2004, 10, 91-95.

[39] D’Flynn C.C., Cruz-Romero M.C., Troy D., Mullen A.M., Kerry J.P.: The application of highpressure treatment in the reduction of salt levels in reduced-phosphate breakfast sausages. Meat Sci., 2014, 96 (3), 1266-1274.

[40] Oprządek J., Oprządek A.: Mięso i produkty mięsne jako żywność funkcjonalna. Przegl. Hod., 2003, 2, 29-31.

[41] Pelser W.M., Linssen J.P.H., Legger A., Houben J.H.: Lipid oxidation in $n$-3 fatty acid enriched Dutch style fermented sausages. Meat Sci., 2007, 75, 1-11.

[42] Pezacki W.: Przetwarzanie jadalnych surowców rzeźnianych. PWN, Warszawa 1984, ss. 173-176.

[43] Picouet P.A., Sala X., Garcia-Gil N., Nolis P., Colleo M., Parella T., Arnau J.: High pressure processing of dry-cured ham: Ultrastructural and molecular changes affecting sodium and water dynamics. Innov. Food Sci. Emerg. Technol., 2012, 16, 335-340.

[44] Piotrowska A., Świąder K., Waszkiewicz-Robak B., Świderski F.: Ocena możliwości zwiększenia zawartości sprzężonych dienów kwasu linolowego (CLA) w mięsie i przetworach mięsnych. Rocz. PZH, 2012, 63 (3), 265-271.

[45] Przysławski J., Bolesławska I.: Tłuszcze pokarmowe - czynnik terapeutyczny czy patogenetyczny. Tłuszcze Jadalne, 2006, 41 (3/4), 179-192.

[46] Pyrcz J., Kowalski R., Danyluk B.: Jakość kutrowanych kiełbas parzonych produkowanych z udziałem tłuszczów roślinnych. Med. Weter., 2007, 63, 118-122. 
[47] Rodrigues I., Trindade M.A., Caramit F.R., Candoğan K., Pokhrel P.R., Barbosa-Cánovas G.V.: Effect of high pressure processing on physicochemical and microbiological properties of marinated beef with reduced sodium content. Innov. Food Sci. Emerg. Technol., 2016, 38, 328-333.

[48] Rozporządzenie Parlamentu Europejskiego i Rady (UE) nr 1169/2011 z dnia 25 października 2011 r. w sprawie przekazywania konsumentom informacji na temat żywności. Dz. Urz. UE L 304, s. 18-63, z 22.11.2011 z późn. zm.

[49] Ruusunen M., Puolanne E.: Reducing sodium intake from meat products. Meat Sci., 2005, 70, 531541.

[50] Rycielska J., Słowiński M.: Próba zastąpienia tłuszczu zwierzęcego olejem rzepakowym w kiełbasach homogenizowanych. Acta Agrophysica, 2012, 19 (1), 123-132.

[51] Sikorski Z.: Interakcje składników żywności. W: Chemia żywności. Tom 3. Odżywcze i zdrowotne właściwości składników żywności. Red. Z. Sikorski. WNT, Warszawa 2007, ss. 211-213.

[52] Słowiński M., Jankiewicz L.: Mięso i przetwory mięsne żywnością funkcjonalną. Gosp. Mięsna, 2010, 62 (4), 10-13.

[53] Dyrekcja Generalna ds. Komunikacji Społecznej (Komisja Europejska): Bezpieczeństwo żywności. Od pola do stołu - bezpieczna i zdrowa żywność dla każdego. Unia Europejska, Luksemburg 2014.

[54] Szterk A., Czerwonka M., Waszkiewicz-Robak B.: Żywność funkcjonalna dla osób prowadzących aktywny tryb życia. Przem. Spoż., 2010, 64 (5), 32-36.

[55] Szczepanik G.: Wpływ ekstraktów kopru, podbiału, rozmarynu, skrzypu, szałwii i tymianku na hamowanie utleniania lipidów wyekstrahowanych z tkanki mięśniowej kurcząt i indyków. Żywność. Nauka. Technologia. Jakość, 2007, 4 (53), 89-98.

[56] Szymański P., Wawrzyniewicz M., Moch P., Plaskota A., Kern-Jędrychowski J.: Tendencje zmian jakościowych wybranych kiełbas suszonych i wędzonek obserwowane w latach 2000 - 2008 na podstawie wyników badań chemicznych produktów zgłaszanych na konkurs „Produkty najwyższej jakości w przemyśle mięsnym”. Rocz. IPMiTł., 2009, XLVII (2), 116-133.

[57] Wojtasik A., Przygoda B., Kunachowicz H.: Analiza zawartości soli w wybranych grupach produktów spożywczych w aspekcie możliwości zmniejszania jej spożycia z dietą. Żyw. Czł. Met., 2010, $37(5 / 6), 355-367$.

[58] PN-A-82007:1996/Az1:1998. Przetwory mięsne. Wędliny.

\title{
MODIFICATION OF NUTRITIONAL VALUE OF MEAT AND MEAT PRODUCTS BY CHANGING QUANTITY AND COMPOSITION OF FATS AND BY REDUCING SALT CONTENT
}

\author{
$\mathrm{S} \mathrm{u} \mathrm{m} \mathrm{m} \mathrm{a} \mathrm{r} \mathrm{y}$
}

In the paper, an analysis was presented of some selected factors that impact the improvement of nutritional value of meat and meat products; the analysis was made on the basis of the reference literature data. Particular attention was paid to the modification of nutritional value of meat and meat products by changing the amount and composition of fats and by reducing the salt content. The nutrients occurring in meat and meat products were discussed and the contents of selected minerals and of vitamins therein were incorporated as was the content of CLA. The profile of animal fats applied in the meat industry was described as were their nutritional and technological role. The importance was discussed of vegetable oils for the modification of fatty acid profile of both the meat and the meat products in order to improve their nutritional value. This effect can be obtained using genetic or nutritional methods. The quantity and quality of fat in carcass largely depends on the composition of feed components in the diet. The use of oilseeds 
or oils to feed fatteners and poultry significantly affects the composition of fatty acids in spare fat and meat lipids. Methods were characterized that are applied to reduce the salt content in meat products. One of the important lines of actions to reduce the amount of salt consumed with the industrially processed products can be to reduce salt quantities added to products as well as to actively shape taste habits of consumers for less salty products. The use of high pressure technology can prove to be an effective method to reduce salt content in meat and meat products.

Key words: meat and meat products, nutritional value, modification of animal fats, reducing salt 